\title{
Caisson Breakwater for LNG and Bulk Terminals: A Study on Limiting Wave Conditions for Caisson Installation
}

\author{
Lin, Yu ; El Chahal, Ghassan ; Shao, Yanlin
}

Published in:

Proceedings of the ASME 2020 39th International Conference on Ocean, Offshore and Arctic Engineering

Link to article, DOI:

10.1115/OMAE2020-19081

Publication date:

2020

Document Version

Peer reviewed version

Link back to DTU Orbit

Citation (APA):

Lin, Y., El Chahal, G., \& Shao, Y. (2020). Caisson Breakwater for LNG and Bulk Terminals: A Study on Limiting Wave Conditions for Caisson Installation. In Proceedings of the ASME 2020 39th International Conference on Ocean, Offshore and Arctic Engineering (Vol. Volume 1: Offshore Technology). [OMAE2020-19081] American Society of Mechanical Engineers. https://doi.org/10.1115/OMAE2020-19081

\section{General rights}

Copyright and moral rights for the publications made accessible in the public portal are retained by the authors and/or other copyright owners and it is a condition of accessing publications that users recognise and abide by the legal requirements associated with these rights.

- Users may download and print one copy of any publication from the public portal for the purpose of private study or research.

- You may not further distribute the material or use it for any profit-making activity or commercial gain

- You may freely distribute the URL identifying the publication in the public portal 


\title{
CAISSON BREAKWATER FOR LNG \& BULK TERMINALS: A STUDY ON LIMITING WAVE CONDITIONS FOR CAISSON INSTALLATION
}

\author{
Yu Lin a, Ghassan El Chahal ${ }^{b}$ and Yanlin Shao ${ }^{a}$ \\ a Technical University of Denmark, Lyngby, Denmark \\ ${ }^{b}$ Marine and Energy, COWI A/S, Lyngby, Denmark
}

\section{ABSTRACT}

As the worldwide oil and gas market continues to grow and environmental concerns with respect to in-port offloading of gas have increased, there has been a boom of interest in new liquefied natural gas LNG terminals in the past years. Loading - offloading operations at LNG and bulk terminals are generally protected by a breakwater to ensure high operability. For these terminals, caisson breakwaters are generally a preferred solution in water depth larger than 15 $m$ due to its advantages compared to rubble mound breakwaters. The caisson installation is generally planned to be carried out in the period where sea conditions are relatively calm. However, many of these terminal locations are exposed to swell conditions, making the installation particularly challenging and subject to large downtime. There is no clear guidance on the caisson installation process rather than contractors' experiences from different projects/sites. Therefore, studies are required in order to provide general guidance on the range of acceptable wave conditions for the installation operations and to have a better understanding of the influence of the caisson geometry.

This paper presents a numerical study to determine the limiting wave conditions for caisson installing operations at larger water depth of 30-35 $\mathrm{m}$ for a confidential project along the African coast. Three caisson sizes/geometries are considered in order to assess and compare the wavestructure hydrodynamic interaction. The linear frequencydomain hydrodynamic analysis is performed for various seastates to determine the limiting wave conditions. Viscous effects due to flow separation at the sharp edges of the caisson are considered by using a stochastic
\end{abstract}

linearization approach, where empirical drag coefficients are used as inputs. Parametric studies on caisson size and mooring stiffness are also presented, which can be used as a basis for future optimization. The uncertainty in the applied empirical viscous drag coefficients taken from the literature is examined by using a range of different drag coefficients. Further, the use of clearance-independent hydrodynamic coefficients (e.g. added mass and damping) may be questionable when the caisson is very close to the seabed, due to a possible strong interaction between caisson bottom and seabed. This effect is also checked quantitatively by a simplified approach.

The findings of the study are presented in the form of curves and generalized to be used by designers and contractors for general guidance in future projects.

\section{INTRODUCTION}

Caisson breakwaters are generally the preferred solution for LNG \& bulk terminals and ports built at water depth larger than $15 \mathrm{~m}$ due to its advantages compared to rubble mound breakwaters such as: material and construction savings, better sheltering of the port side as caisson do not allow wave transmission through it, smaller footprint resulting in reduced environmental impact to the seabed and surrounding environment and finally caisson fabrication is conducted in sheltered areas independent of sea conditions, therefore, reducing risks of construction delays. The installation of caisson breakwaters is expensive with high daily mobilization costs and specialized equipment. Even though the caisson installation is generally planned to be carried out in the period where sea conditions are relatively calm, it is inevitable to operate under swell conditions resulting in large downtime. 
The installation wave window for caissons has been always a critical element in caisson breakwater projects due to a large number of caissons to be installed, which can extend over months. In some projects, contractors have decided to deviate from a caisson solution to other alternative structures due to the lack of clear methodology for caisson installation in locations exposed to long period swells. Furthermore, in deeper water locations (around $35 \mathrm{~m}$ depth) there is always a choice between large caissons placed on a small rubble mound foundation and smaller caissons placed on a larger rubble mound foundation. The final decision for the caisson size is mainly based on the construction costs of concrete caisson works versus the rubble mound foundation. However, the aspect of the caisson size and allowable wave window installation (downtime) which have an impact on the overall installation operations are generally not considered in the value engineering and optimization phase. When the caissons are small, the oscillation/motion due to wave action is larger than that of big caissons during installation.

If the caisson is sunk down and settled on the top of the rubble mound before the oscillation becomes small, it may not only result in low accuracy of the installation but also high probability that an accident can occur. For example, the oscillating caisson and the rubble mound may be damaged in the collision. Therefore, the work shall be halted for a while just before the caisson is sunken down to the predetermined position to maintain the accuracy and safety of the installation work. For operating efficiency, it is desirable to minimize this waiting time. It is generally reported that large heave motion close to $1 \mathrm{~m}$ would make final positioning difficult as large oscillations close to the rubble mound foundation can cause structural damage due to collision.

Due to the lack of clear guidance or methodology on this subject, more studies are required for the range of acceptable wave conditions for caisson installation based on caisson predicted motion response. This paper presents a numerical study to determine the limiting wave conditions for caisson installing operations at larger water depth of 30$35 \mathrm{~m}$ along the African coast. The work presented here is for an actual project and therefore, locations, references and details are kept confidential. However, it shall be noted that these caisson installation challenges are similar for other locations exposed to large swells and can be thus generalized.

Two critical loading conditions during caisson installations are considered: (1) the caisson is in final position awaiting for sinking, where stability under wave effects is important; (2) ballasted/immersed conditions with caisson approximately $1 \mathrm{~m}$ above seabed, where there is small clearance between caisson and seabed and excessive motion must be avoided due to risk of collision with rubble mound foundation. In both scenarios, the caissons are still afloat and motions are governed by the wave-structure interaction. Three caissons with different geometry/weight have been considered to cover a wide range of caisson breakwaters.

\section{CAISSON GEOMETRY, LOADING CONDITIONS}

\subsection{Caisson geometry}

The caissons considered in this study have rectangular shapes, which are commonly used in caisson designs. Typical caissons contain vertical outer walls, vertical interior walls and a bottom, all made of concrete. The interior vertical walls divide the space into compartments, which are designed to be ballasted. The seawater is used as initial ballast for stabilizing during the installation. After the caisson is set on the mound foundation, the ballast water will be replaced by sand at the end of the whole installation process.

Defining the caisson geometry and size is a complicated process as normally determined by the caisson functional requirements in case used a quay/berth structure or only a breakwater, overall stability, casting yard equipment/facility, the capacity of floating dock for transportation in addition to other projects constraints. In deep-water locations, there is always a choice between large caissons placed on a small rubble mound foundation and smaller caissons placed on a larger rubble mound foundation. Furthermore, for long breakwaters installed along varying water depth different caisson sizes are required. For practicality reasons of caissons casting/fabrication, caissons of the same width and length are used and only height is varied.

In this paper, three sizes of caissons are studied assuming varying height, i.e same width and length. The sizes of the caissons are shown in Table 1. The sketch of the structure of caisson shown in Fig. 1 presents the caisson types and positions considered in the study.

Table 1 Main dimensions of the three caissons

\begin{tabular}{l|ccl}
\hline Caissons & $\begin{array}{c}\text { Height } \\
(\boldsymbol{m})\end{array}$ & $\begin{array}{c}\text { Length } \\
(\boldsymbol{m})\end{array}$ & $\begin{array}{c}\text { Width } \\
(\boldsymbol{m})\end{array}$ \\
\hline Caisson1 & 32 & 30 & 30 \\
Caisson2 & 27 & 30 & 30 \\
Caisson3 & 22 & 30 & 30 \\
\hline
\end{tabular}

\subsection{Loading conditions}

The caissons are fabricated at an onshore yard, transported by sea to the project site, and sunk down on the rubble mound foundation by ballasting, i.e. pumping water into the caisson compartments. In this working process, the caissons are in a floating state, so they are always oscillating under dynamic wave action. Two critical scenarios (loading conditions) will be considered in this 
paper. In the first scenario, hereafter called 'position 1', the caisson has been towed by tugs to the installation site but waiting for further action, e.g. pumping of ballast water. The second loading condition, called 'position 2' in the paper, refers to the condition where caisson is waiting for final placement with a small clearance (typically $1 \mathrm{~m}$ ) above the mound foundation.

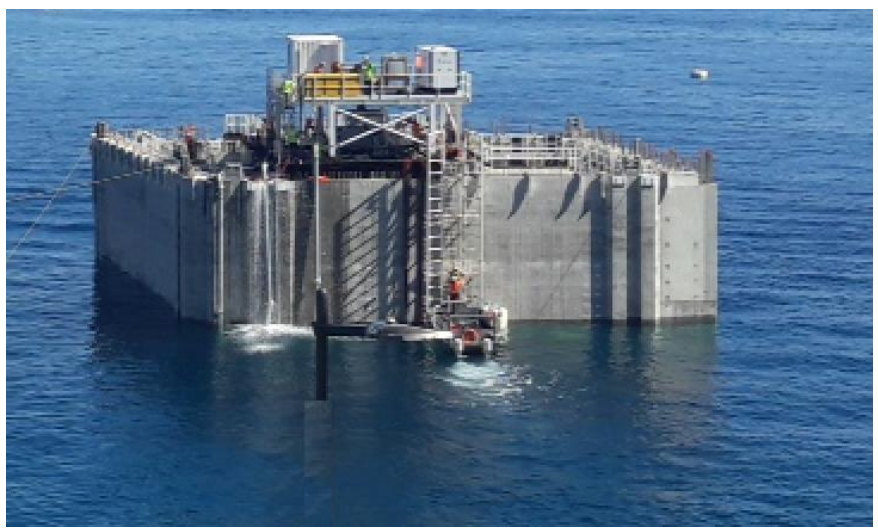

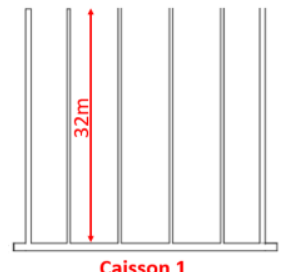

Caisson 1

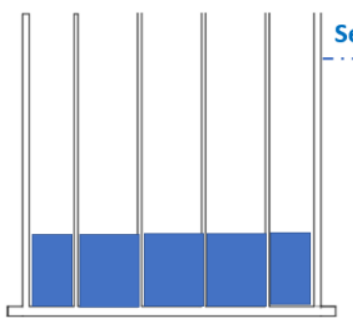

Position 1

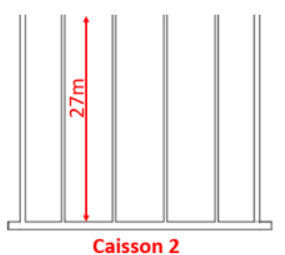

Caisson 2 Sea level -...-.-

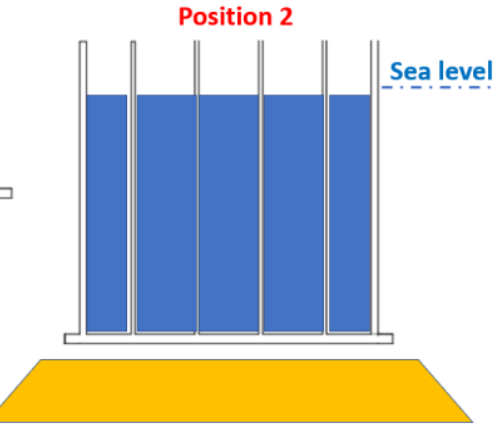

Fig. 1 Caisson in water (upper), three caisson types (middle), caisson positions (lower). Position 1: floating, Position 2: immersed near the seabed.

The static stability of floating structures is checked by calculating the metacentric height (GM), which is the distance between the center of gravity and the metacenter. Caissons are considered to be stable during transport if the metacentric height is at least $0.50 \mathrm{~m}$. However, for practical reasons, GM larger than $1 \mathrm{~m}$ is generally considered. Normally partial water ballast inside the caisson is required in order to increase the metacentric height during transport. The results of gyration radius and center of gravity for two working conditions are displayed in Table 2 and Table 3.
It should be noted that not only the static stability but also the dynamic stability should be checked. Worse than caisson swaying due to waves or swell, is the vertical movement of a structure if the wave period comes closer to the natural oscillation period (eigen period) of the structure. In order to prevent this, one must ensure that the natural oscillation period of the element is significantly larger or smaller than that of the waves or swell.

Table 2 Gyration radius of three caissons for position 1: floating at the final position.

\begin{tabular}{c|cccc}
\hline $\begin{array}{c}\text { Caisson } \\
\text { ID }\end{array}$ & $\begin{array}{c}\boldsymbol{R}_{\boldsymbol{x} \boldsymbol{x}} \\
{[\mathrm{m}]}\end{array}$ & $\begin{array}{c}\boldsymbol{R}_{\boldsymbol{y} \boldsymbol{y}} \\
{[\mathrm{m}]}\end{array}$ & $\begin{array}{c}\boldsymbol{R}_{\boldsymbol{z z}} \\
{[\mathrm{m}]}\end{array}$ & $\begin{array}{c}\boldsymbol{C O G} \\
{[\mathrm{m}]}\end{array}$ \\
\hline Caisson1 & 13.00 & 13.45 & 12.69 & 12.72 \\
Caisson2 & 11.87 & 12.41 & 12.65 & 10.98 \\
Caisson3 & 10.58 & 11.22 & 12.57 & 9.78 \\
\hline
\end{tabular}

Table 3 Gyration radius of caissons for position 2: immersed near the foundation.

\begin{tabular}{c|cccc}
\hline $\begin{array}{c}\text { Caisson } \\
\boldsymbol{I D}\end{array}$ & $\begin{array}{c}\boldsymbol{R}_{\boldsymbol{x x}} \\
{[\mathrm{m}]}\end{array}$ & $\begin{array}{c}\boldsymbol{R}_{\boldsymbol{y y}} \\
{[\mathrm{m}]}\end{array}$ & $\begin{array}{c}\boldsymbol{R}_{\boldsymbol{z z}} \\
{[\mathrm{m}]}\end{array}$ & $\begin{array}{c}\boldsymbol{C O G} \\
{[\mathrm{m}]}\end{array}$ \\
\hline Caisson1 & 12.53 & 12.82 & 12.61 & 12.11 \\
Caisson2 & 11.66 & 12.08 & 12.57 & 10.29 \\
Caisson3 & 10.77 & 11.27 & 12.49 & 8.60 \\
\hline
\end{tabular}

For position 1, where the caisson is in-position awaiting for sinking, initial ballast water is used to stabilize the caisson. The amount of ballast water required together with the caisson weights for three different sizes at position 1 is shown in Table 4.

Table 4 The volume of ballast water, concrete weights and total weights of the three caissons at position 1.

\begin{tabular}{l|ccccr}
\hline $\begin{array}{c}\text { Caisson } \\
\text { ID }\end{array}$ & $\begin{array}{c}\text { Concrete } \\
\text { weight } \\
\text { [ton] }\end{array}$ & $\begin{array}{c}\text { Draft } \\
{[\mathrm{m}]}\end{array}$ & $\begin{array}{c}\text { Ballast } \\
\text { water } \\
{[\mathrm{m}]}\end{array}$ & $\begin{array}{c}\text { Total } \\
\text { weight } \\
{[\text { ton] }}\end{array}$ & $\begin{array}{c}\text { GM } \\
{[\mathrm{m}]}\end{array}$ \\
\hline Caisson 1 & 15,904 & 22.8 & 5 & 19,252 & 1.19 \\
Caisson 2 & 13,771 & 18.7 & 3 & 15,780 & 1.45 \\
Caisson 3 & 11,638 & 13.7 & 0 & 11,638 & 1.3 \\
\hline
\end{tabular}

For position 2, which is the immersed condition, the caisson is filled with ballast water to sink until there is approximately $1 \mathrm{~m}$ clearance between the caisson and the foundation on the seabed. The detail information is shown in Table 5.

Table 5 Amount of ballast water, concrete weights and total weights of the three caissons at position 2 .

\begin{tabular}{c|ccc}
\hline $\begin{array}{c}\text { Caisson } \\
\text { ID }\end{array}$ & $\begin{array}{c}\text { Concrete } \\
\text { weight } \\
\text { [ton] }\end{array}$ & $\begin{array}{c}\text { Ballast } \\
\text { water } \\
{[\mathrm{m}]}\end{array}$ & $\begin{array}{c}\text { Total } \\
\text { weight } \\
{[\text { ton] }}\end{array}$ \\
\hline Caisson 1 & 15,904 & 9.5 & 22,378 \\
Caisson 2 & 13,771 & 6.5 & 18,169 \\
Caisson 3 & 11,638 & 3.5 & 13,959 \\
\hline
\end{tabular}




\subsection{Mooring configuration}

The caissons are transported to their final position by floating docks/barges or moored by tugboats depending on water depth at the site. A mooring system is applied to limit the motion of the caisson during the process of installation. Polypropylene and metallic cables of high strength are generally used. The 4-lines mooring system is considered here. The properties of the mooring lines are shown in Table 6 . Four mooring lines of metallic cable type having the same material and size are considered.

Table 6 Mooring lines property.

\begin{tabular}{l|ccc}
\hline $\begin{array}{l}\text { Mooring } \\
\text { Line }\end{array}$ & $\begin{array}{c}\text { Length } \\
(\mathrm{m})\end{array}$ & $\begin{array}{c}\text { Diameter } \\
(\mathrm{m})\end{array}$ & $\begin{array}{l}\text { Young's } \\
\text { Modulus }\end{array}$ \\
\hline & 100 & 0.052 & $1.12 \mathrm{e}+11$ \\
\hline
\end{tabular}

The mooring lines are connected to the corners of the caisson and assumed to be straining along the free surface. An example of a mooring system configuration is sketched in Fig. 2 .

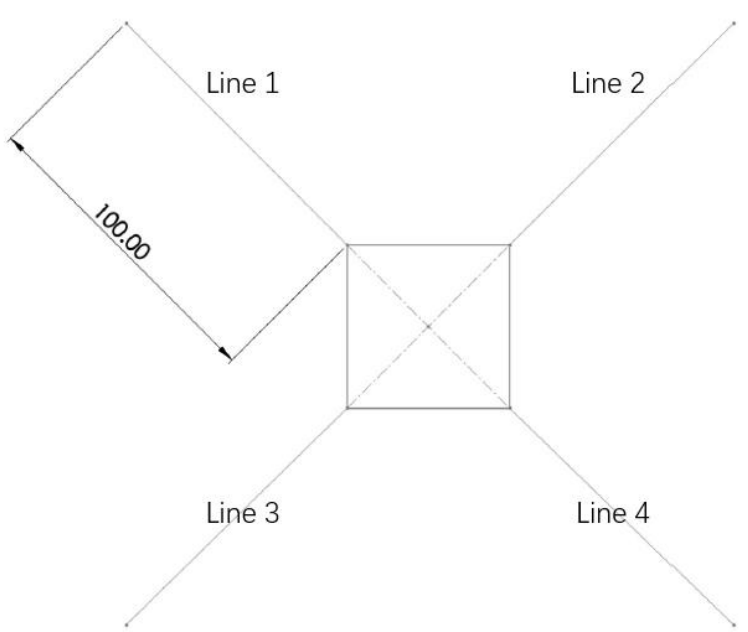

Fig. 2 Configuration of an example of the mooring system.

The mooring system will provide extra stiffness matrix performing in equations of motion. The specific mooring system matrix for six degrees of freedom is derived from Hooke's law. The reference point for rotational motions is set as the Center of Gravity ( $\mathrm{CoG}$ ) of the caisson. For the reference mooring system presented in Fig.2, the extra stiffness matrix $\boldsymbol{C}_{\boldsymbol{e}}$ is computed and included in the motion equations that will be presented in Section 3.3.

\section{LINEARIZED FREQUENCY-DOMAIN HYDRODYNMAMIC MODELLING}

Since a large number of seastates, different caisson sizes and loading conditions are analyzed in this paper, a frequency-domain hydrodynamic analysis is applied together with a stochastic linearization of the viscous drag loads on the bottom of the caisson. The theoretical background of the stochastic linearization is described in Borgman (1967) and Wolfram (1998). An implementation of this procedure is described in Shao et al. (2016, 2019) and has been applied in the hydrodynamic analysis of cylindrical FPSOs and pontoons of floating bridges.

\subsection{Morison elements}

The drag forces and moments due to viscous flow separation at the bottom plate are modeled by Morison elements. In this paper, Morison elements are only distributed along the square edges which are illustrated by the red dashed line in Fig.3. The defined Morison elements will give only vertical drag force and moment on the bottom plate. Each of the 4 edges contains 10 Morison elements for all the caissons.

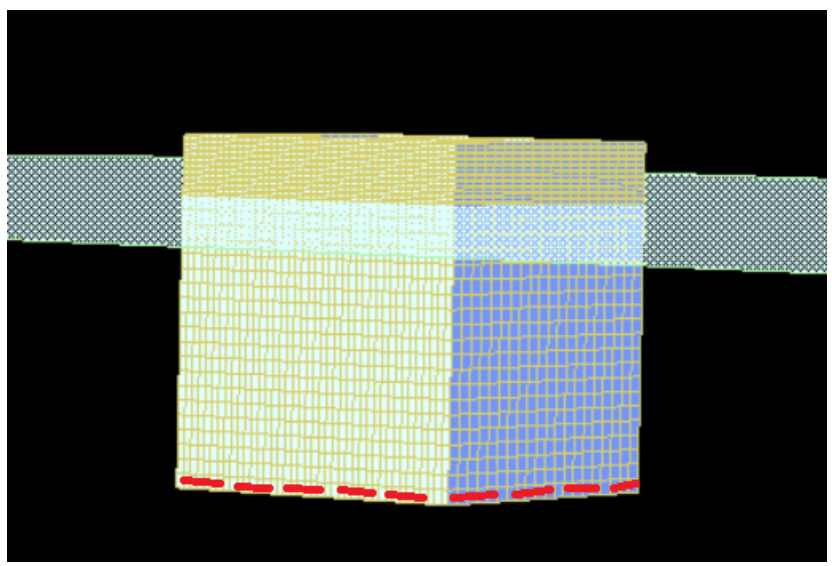

Fig. 3 Caisson Panel model in HydroD and the location of Morison elements along the edges of the bottom slab.

\subsection{Stochastic linearization in irregular waves}

From Morison's equation, the transverse force $d F$ on a strip of length $d z$ of a longitudinal cylinder is defined as:

$$
d F=\frac{\rho \pi D^{2}}{4} d z\left(1+C_{m}\right) a+\frac{\rho}{2} C_{D} D d z u|u|
$$

where $\rho$ is the density of the fluid. $D$ is the diameter of the cylinder. $u$ and $a$ are the undisturbed fluid velocity and acceleration, respectively. $C_{m}$ and $C_{D}$ are the added mass and drag coefficients, respectively.

Considering the effect of viscous flow, the added mass coefficient can be expressed as:

$$
C_{m}=C_{m}^{p o t}+C_{m}^{v i s} .
$$

where $C_{m}^{\text {pot }}$ is the added mass coefficient due to potential flow alone while $C_{m}^{v i s}$ is regarded as the viscous correction to the added mass coefficient.

To use the drag terms of Morison's equation in a frequency-domain hydrodynamic analysis, linearization is needed. Since wave elevation is considered as a stochastic process, the stochastic linearization is more rational than a linearization method based on regular waves only. 
In irregular-wave stochastic linearization, the drag force on a strip of length $d l$ of a Morison element is expressed as:

$d F_{D} \approx \frac{1}{2} \rho \boldsymbol{C}_{\boldsymbol{D}} D \sqrt{\frac{8}{\pi}} \sigma_{|v-\dot{x}|}(\boldsymbol{v}-\dot{\boldsymbol{x}}) d l=b_{v}(\boldsymbol{v}-\dot{\boldsymbol{x}})$

where,

$$
\boldsymbol{b}_{v}=\frac{1}{2} \rho \boldsymbol{C}_{\boldsymbol{D}} D \sqrt{\frac{8}{\pi}} \sigma_{|v-\dot{x}|} d l .
$$

Here $v$ is the ambient flow velocity. $\dot{x}$ is the motion velocity of the strip. $\sigma_{|v-\dot{x}|}$ is the standard deviation of the amplitude of the relative velocity between ambient flow and the rigid-body motion at the location of the Morison element. $\boldsymbol{b}_{v}$ represents the linearized damping coefficient contributed by a strip of length $d l$. The equivalent damping coefficient can be obtained by integrating $d F_{D}$ along the Morison elements.

\subsection{Equation of motion}

The equation of motion in linear theory for a floating structure is defined as [1])

$$
\begin{aligned}
& {\left[-\omega^{2}(\boldsymbol{M}+\boldsymbol{A}(\omega))-i \omega \boldsymbol{B}(\omega)+\left(\boldsymbol{C}+\boldsymbol{C}_{\boldsymbol{e}}\right)\right] \boldsymbol{X}} \\
& =\boldsymbol{F}_{\text {exc }}(\omega, \beta)+\boldsymbol{F}_{\text {mori }}
\end{aligned}
$$

Where,

$\omega:$ wave frequency

$\beta$ : Wave heading

$\boldsymbol{M}$ : Mass matrix of the floating structure

$\boldsymbol{A}(\omega)$ : Added mass matrix

$\boldsymbol{B}(\omega)$ : Potential flow damping matrix

$\boldsymbol{C}$ : Hydrostatic restoring matrix

$\boldsymbol{C}_{\boldsymbol{e}}$ : External restoring matrix due to, e. g. mooring

$\boldsymbol{X}$ : Rigid body motion vector

$\boldsymbol{F}_{\text {exc }}(\omega, \beta):$ Wave excitation due to potential flow

$\boldsymbol{F}_{\text {mori }}$ : Morison load vector

By combining the inertia force and equivalently drag forces on Morison elements, the equation of motion can be derived as:

$\left\{\begin{array}{c}-\omega^{2}\left(\boldsymbol{M}+\boldsymbol{A}(\omega)+\boldsymbol{A}_{\text {mori }}\right) \\ -i \omega\left(\boldsymbol{B}(\omega)+\boldsymbol{B}_{\text {mori }}\right) \\ +\left(\boldsymbol{C}+\boldsymbol{C}_{\boldsymbol{e}}\right)\end{array}\right\} \boldsymbol{X}=\boldsymbol{F}_{\text {exc }}(\omega, \beta)+\boldsymbol{F}_{\text {exc }, \text { mori }}$

Here $\boldsymbol{B}_{\text {mori }}$ is the equivalently linearized damping matrix. $\boldsymbol{A}_{\text {mori }}$ is the viscous correction of added mass matrix contributed by the Morison elements, which will be ignored in this study. $\boldsymbol{F}_{\text {exc,mori }}$ is the excitation force due to drag loads on Morison elements. Note that the Morison elements are not related to the restoring matrix since they are rigid and fully submerged. Since $\boldsymbol{B}_{\text {mori }}$ depends on the rigid-body motion $\boldsymbol{X}$, the motion equations will be nonlinear, which are solved iteratively.

The frequency-domain added mass coefficients, radiation damping coefficients and excitation forces are calculated by the DNVGL hydrodynamic code HydroD /WADAM.

\subsection{Selection of drag coefficient}

The drag loads (heave force and pitch/roll moments) on the bottom of the caisson will be considered in the motion equations through the stochastic linearization described in Section 3.2. The total drag force in heave can be expressed as

$$
F_{d, \text { heave }}=\frac{1}{2} \rho C_{d, \text { heave }} A_{p}\left|v_{\text {rel }}\right| v_{\text {rel }} .
$$

Here $A_{p}$ is the projection area of the caisson bottom to heave motion. $v_{\text {rel }}$ is the relative velocity between caisson and ambient incident waves at the center of the caisson bottom. $C_{d \text {,heave }}$ is the drag coefficient. For structures with sharp edges, the drag coefficient is mainly dependent on Keulegan-Carpenter (KC) number, because the flow will separate at fixed locations, i.e. the sharp edges. See discussion in Tao and Thiagarajan (2003a, 2003b) and Shao et al. $(2016,2019)$. It also indicates that scale effects in the modeling of the drag forces and the viscous damping are not significant from a design point of view.

A good estimation of the drag coefficient is essential in the motion analysis of the caisson. At this stage, we have not done tailor-made experiments or sophisticated Computational Fluid Dynamic (CFD) analysis for our caisson designs. However, there are studies in the literature for other types of marine structures that may be relevant for us to make a rough estimation of the drag coefficients.

For the supporting pontoons of floating bridges which have sharp edges but without bottom flanges, $\mathrm{Xu}$ et al. (2016) has estimated from the literature that the drag coefficient $C_{d}$ could vary between 4.0 and 10 . It was later confirmed by Shao et al. (2019) that using $C_{d} \approx 5.0$ gives very good agreement between their numerical analysis and experiments for the studied pontoons. In caisson designs, the bottom slab extends outside the external walls forming a bottom flange (typically of a width of $0.5 \mathrm{~m}$ to $1.0 \mathrm{~m}$ ), and therefore it is expected to have higher drag coefficients than that without bottom flange.

None of the above-mentioned studies has considered the structure-seabed interaction in the estimation of drag coefficients. Nevertheless, the drag coefficient can be strongly influenced by the interaction between the seafloor and the bottom plate of the structures, especially when the clearance below the structure is very small compared with the characteristic dimension of the bottom plate. GarridoMendoza (2015) studied the forced harmonic oscillation of a circular disk experimentally in a wave flume and numerically using OpenFoam. The drag coefficients were seen to increase dramatically when the clearance below the disk is small. A regression analysis on the numerical results of linearized damping was made, which indicates the following clearance dependence of the drag coefficients (derived based on Eq.5.6 in Garrido-Mendoza 2015)

$$
\frac{C_{d, \text { heave }}(\bar{h})}{C_{d, \text { heave }}(\bar{h}=\infty)}=0.95 \bar{h}^{-0.55} K C+\frac{0.02}{\bar{h}}+0.2 \text {. }
$$


Here $\bar{h}=\frac{h}{r_{d}} . h$ is the clearance between the disk and seafloor. $r_{d}$ is the radius of the disk. $K C=\frac{\pi \eta_{3 m}}{r_{d}}$ is the Keulegan-Carpenter number, where $\eta_{3 m}$ is the heaving amplitude.

In order to use Eq.(8) to roughly estimate $C_{d \text {,heave }}$ for the present study, we will use $r_{d}=\sqrt{A_{p} / \pi}=17 \mathrm{~m}$. In the later operational limit analyses that will be presented in Section 4, we consider two allowable criteria for loading condition 'position 2', namely $1.0 \mathrm{~m}$ and $0.5 \mathrm{~m}$ above the mound foundation. The parameters are presented in Table 7. For both cases, the clearance-dependent drag coefficient $C_{d, \text { heave }}$ seems to be around 5.0 times the drag coefficient in deep water. Thus, $C_{d, \text { heave }}=5 \cdot C_{d \text {,heave }}(\infty)$ is used in all the analyses in Section 4 if drag forces will be modeled.

Table 7 Parameters used for the estimation of clearancedependent drag coefficients.

\begin{tabular}{c|cccc}
\hline $\begin{array}{c}\boldsymbol{h} \\
{[\mathrm{m}]}\end{array}$ & $\begin{array}{c}\boldsymbol{\eta}_{\mathbf{3 m}} \\
{[\mathrm{m}]}\end{array}$ & $\boldsymbol{K C}$ & $\overline{\boldsymbol{h}}$ & $\frac{\boldsymbol{C}_{\boldsymbol{d} \text {,heave }}(\bar{h})}{\boldsymbol{C}_{\boldsymbol{d}, \text { heave }}(\bar{h}=\infty)}$ \\
\hline 1 & 0.5 & 0.09 & 0.06 & 4.79 \\
1.5 & 1 & 0.18 & 0.09 & 5.47 \\
\hline
\end{tabular}

It should be noted that the estimation in Table 6 deems to be a rough one for the following several reasons: (1) The regression analysis leading to Eq.(8) was based on numerical results for $\bar{h}=[0.2,0.3,0.4,0.5,1.0,2.0]$, while the relevant $\bar{h}$ values in our cases are out of this range; (2) The considered structure in this study is different from that in Garrido-Mendoza (2015), where a thin circular disk was considered. However, it is not the focus of this paper to pursue a very accurate estimation of $K C$-dependent and clearance-dependent drag coefficients, but rather we will consider different drag coefficients to check their effects on the results and to understand the uncertainties in our numerical calculations. Therefore, we will use $C_{d \text {,heave }}=5$. $5=25$ as a reference case but also study two other different drag coefficients $C_{d, \text { heave }}=5 \cdot 4=20$ and $C_{d \text {, heave }}=5 \cdot 6=$ 30 as a sensitivity study

\section{NUMERICAL RESULTS}

A large number of seastates is considered in order to assess the operational limit of the caisson installation. For each seastate, the RAOs are calculated by taking into account the linearized viscous drag loads based on stochastic linearization. Thereafter, the extreme values of motion responses in terms of Most Probable Maximum (MPM) for 3 hours can be estimated.

The selection of the drag coefficient is based on empirical values from the literature. In the results with the linearized drag load presented in Section 4.2, a drag coefficient of 5.0 has been used. A sensitivity study on the drag coefficients will be presented in Section 4.3, together with that on the mooring system and nonlinearity of added mass due to a narrow gap between the caisson bottom and seabed.

\subsection{Sea states matrix}

The seastates applied in the simulations consist of series of $H_{m o}$ (significant wave height) and $T_{p}$ (wave periods). The considered $H_{m o}$ values cover a range between $0.5 \mathrm{~m}$ and 2 $m$ with an increment of $0.2 \mathrm{~m}$. The considered $T_{p}$ values cover a range between $5 s$ and $15 s$, with an increment of $0.5 s$ representing wind seas and swell conditions. Due to the symmetry of the caisson geometry, only the wave headings of $0 \mathrm{deg}$ and $45 \mathrm{deg}$ are considered, i.e perpendicular attack to the wall and an oblique attack. JONSWAP wave spectrum is used. Only unidirectional waves are considered as more relevant to swell waves.

Stochastic linearization of the quadratic drag loads involves the standard deviation of the responses in given seastate, thus the RAOs will be different for different seastates.

All the four lower-corners of the caisson are taken into account to obtain the maximum vertical motion between caisson and seabed. For each caisson size in floating position or in installation position, all the seastates combinations are calculated to verify if the current sea state is safe to operate.

\subsection{RAO results}

The RAO results are calculated for several cases in order to assess the influence of drag and mooring parameters.

\subsubsection{No viscous drag and no mooring}

The results of caisson 1 are shown below. The label position 1 indicates the floating condition and position 2 indicates the immerged condition $1 \mathrm{~m}$ above the foundation. Only results for $45 \mathrm{deg}$ waves are presented as an example. Fig.4, Fig. 5 and Fig. 6 represent the RAO results of heave, pitch and sway motion respectively, while the wave period indicates $\mathrm{Tp}$.

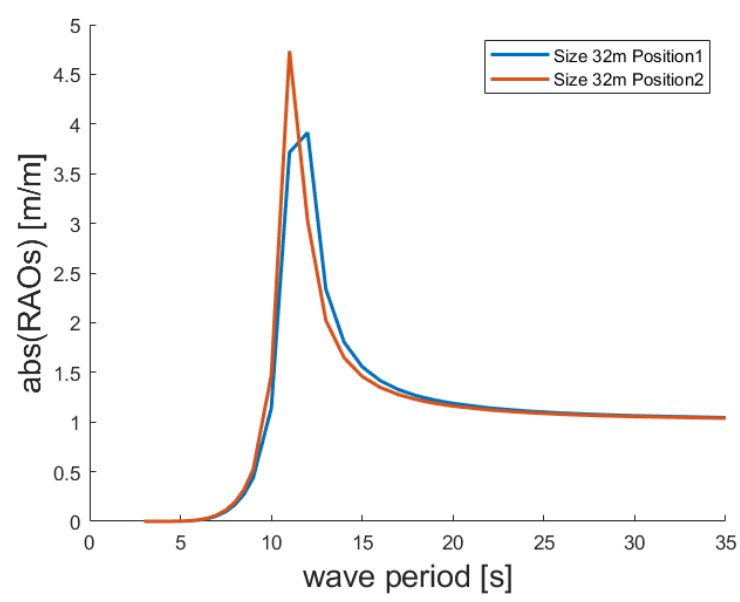

Fig. 4 Heave RAOs of Caisson 1 at position 1 and position 2. Incident waves come from $45 \mathrm{deg}$. 


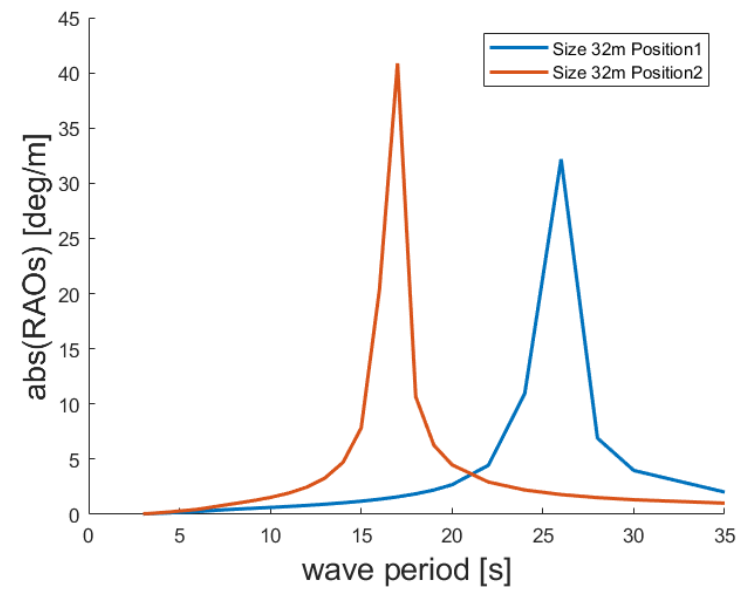

Fig. 5 Pitch RAOs of Caisson 1 at position 1 and position 2. Incident waves come from $45 \mathrm{deg}$.

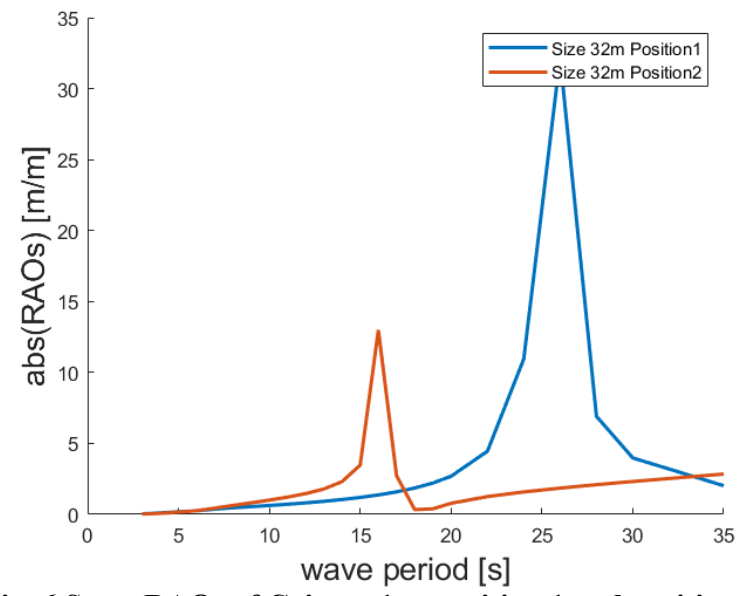

Fig. 6 Sway RAOs of Caisson 1 at position 1 and position 2. Incident waves come from $45 \mathrm{deg}$.

The resonance peaks occur at different frequencies for the two positions, i.e frequency shifts once the caisson is immersed in the water. For the same caisson, the natural period of heave motion is almost unchanged for the two positions. The pitch natural period increases slightly from position 1 to position 2 . The higher heave motion in loaded condition may be explained by the increase of mass of the dynamic system. The lower pitch natural period in the loaded condition is due to higher pitch restoring coefficients, expressed as:

$$
C_{55}=\rho g \iint_{A_{w}} x^{2} d s+\rho g V\left(Z_{B}-Z_{G}\right)
$$

where

$\boldsymbol{A}_{\boldsymbol{w}}$ : the water plane area

$V:$ the volume of the discharged water

$Z_{B}$ : the height of center of buoyancy

$Z_{G}$ : the height of center of gravity

\subsubsection{With viscous drag and no mooring}

By implementing the stochastic linearization, the damping coefficients contributed by Morison elements are considered. Here the drag coefficient for the bottom slab is set as 5.0. The comparisons between cases with/without viscous drag for the caisson 1 under a certain sea state are shown below in Fig.7, Fig.8 and Fig.9 where the dashed line indicates the case with viscous drag.

The RAOs with/without viscous damping show a significant difference, especially for pitch motion. The viscous damping decreases the response for heave and surge motions as well.

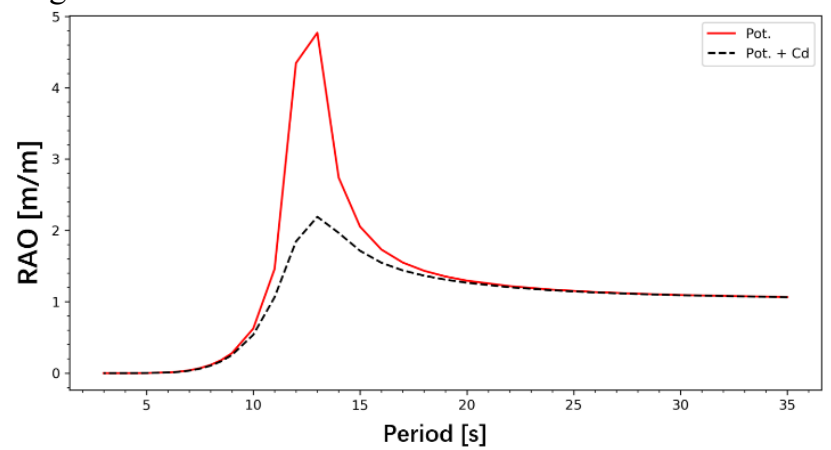

Fig. 7 Heave RAO of Caisson 1 in position 2 with and without viscous drag. $\mathrm{H}_{\mathrm{mo}}=0.9 \mathrm{~m}$. $\mathrm{Tp}=12.5 \mathrm{~s}$. Viscous drag coefficient $=$ 5.0 was used for 'Pot. + Cd'.

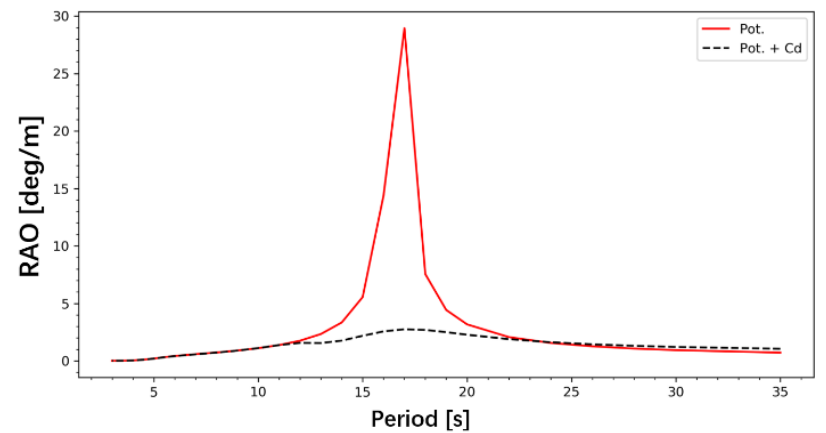

Fig. 8 Pitch RAO of Caisson 1 in position 2 with and without viscous drag. $\mathrm{H}_{\mathrm{mo}}=0.9 \mathrm{~m}$. $\mathrm{Tp}=12.5 \mathrm{~s}$. Viscous drag coefficient $=$ 5.0 was used for 'Pot. + Cd'.

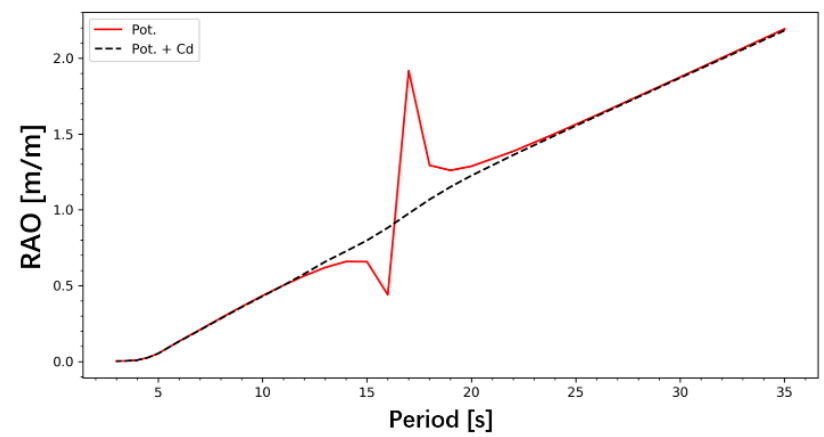

Fig. 9 Surge RAO of Caisson 1 in position 2 with and without viscous drag. $\mathrm{H}_{\mathrm{mo}}=0.9 \mathrm{~m}$. $\mathrm{Tp}=12.5 \mathrm{~s}$. Viscous drag coefficient $=5.0$ was used for 'Pot. + Cd'. 


\subsubsection{With mooring and no viscous drag}

The mooring system provides stiffness to the wave-caisson interaction system. The mooring system assumed here consists of mooring lines attached to the four corners and along the diagonal line of the caisson. This means that in any wave forcing direction, two of the lines will be fully active in order to restore the caisson to its position. In order to have a better understanding of each parameter separately, the simulations here are made with the mooring system but without considering viscous damping. The RAOs with mooring stiffness effects included are shown in Fig.10, 11 and 12 .

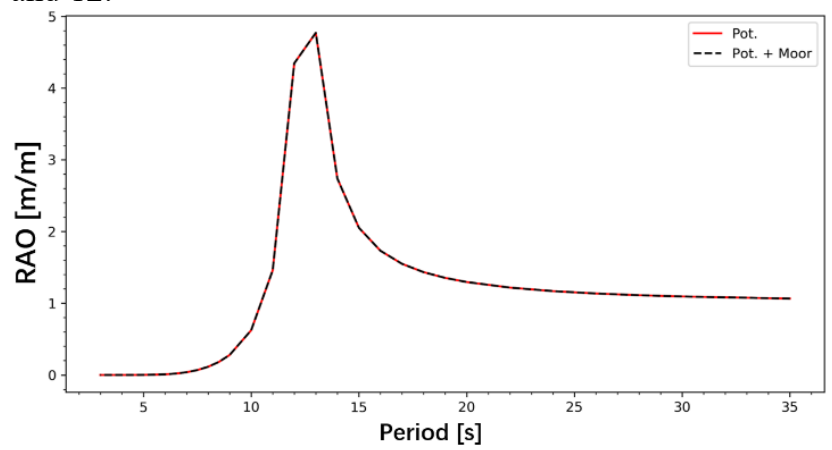

Fig. 10 Heave RAO of caisson size 32 in submerged position with and without mooring. $H_{m 0}=0.9 \mathrm{~m}$. $T p=12.5 \mathrm{~s}$. The extra restoring matrix in Section 2.3 was applied for 'Pot. + Moor'.

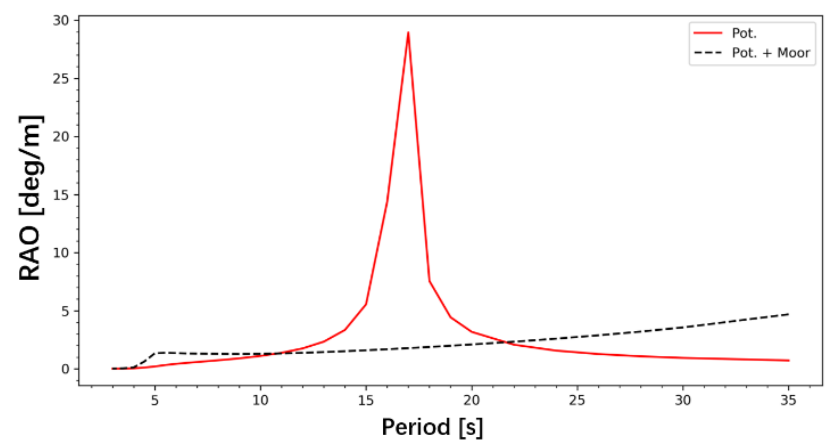

Fig. 11 Pitch RAO of caisson size 32 in submerged position with and without mooring. $H_{m 0}=0.9 \mathrm{~m}$. $T p=12.5 \mathrm{~s}$. The extra restoring matrix in Section 2.3 was applied for 'Pot. + Moor'.

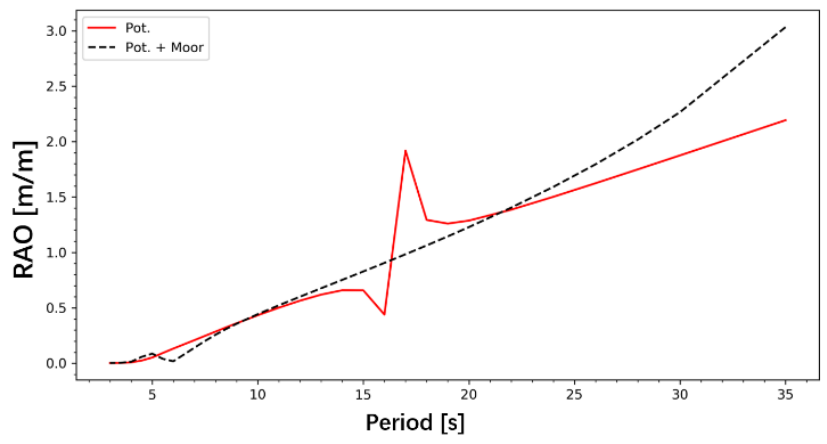

Fig. 12 Surge RAO of caisson size 32 in submerged position with and without mooring. $H_{m o}=0.9 \mathrm{~m}$. $T p=12.5 \mathrm{~s}$. The extra restoring matrix in Section 2.3 was applied for 'Pot. + Moor'.
From the comparison of the RAOs withlwithout mooring system, the mooring system mostly affects the pitch RAO, but it is obvious that has no effect on heave $\mathrm{RAO}$. The pitch RAO has no more resonance and is almost flat.

\subsection{Sensitivity studies}

To assess the uncertainty of the governing factors, sensitivity studies are carried out for the mooring system, drag coefficient and possible nonlinearity due to small clearance below the caisson.

\subsubsection{Mooring system}

In addition to the mooring system presented in Section 2.3, two other mooring systems with the same rope properties but different lengths are also considered. The shorter one has half-length of the example in Section 2.3 leading to doubled restoring coefficients, while the other has a twice length of that example mooring system leading to halved restoring coefficients. Since the pitch motion is the most affected, the pitch motion RAOs are assessed. The sea state with $H_{m o}=0.9 \mathrm{~m}$ and $T_{p}=12.5 \mathrm{~s}$ is considered. The results from halved, original and doubled stiffness are shown in Fig.13 and Fig.14. Since the mooring system will not affect the heave RAOs, the heave motion is not discussed. A drag coefficient of 25 has been applied in this sensitivity study.

The halved stiffness mooring system gives a highly peaked RAO. The doubled stiffness shows the best result without a resonance peak. Fig 15 shows that the doubled stiffness gives the same response as the original mooring for periods longer than $10 \mathrm{~s}$ but allows higher operational conditions for shorter periods. The comparison of operation windows with different mooring system is shown in Fig 15.

The halved stiffness mooring system gives the worst operation window. The original one and the doubled stiffness one compute similar operational conditions. The mooring system plays an important role in the RAOs tendency.

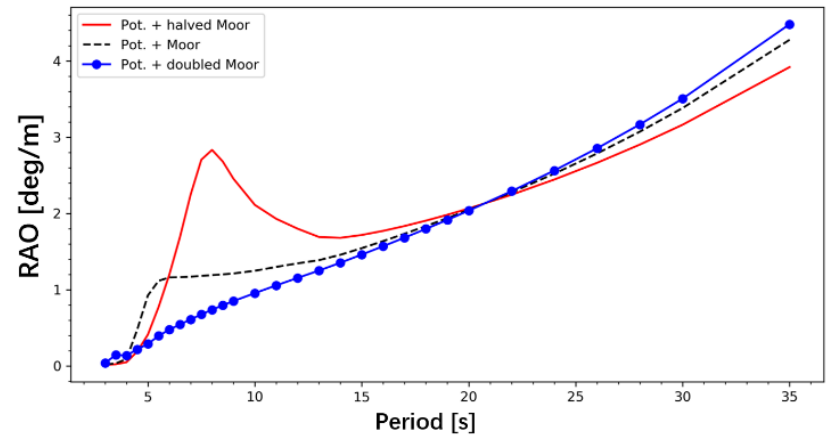

Fig. 13 Pitch RAO with three different stiffness mooring systems. 


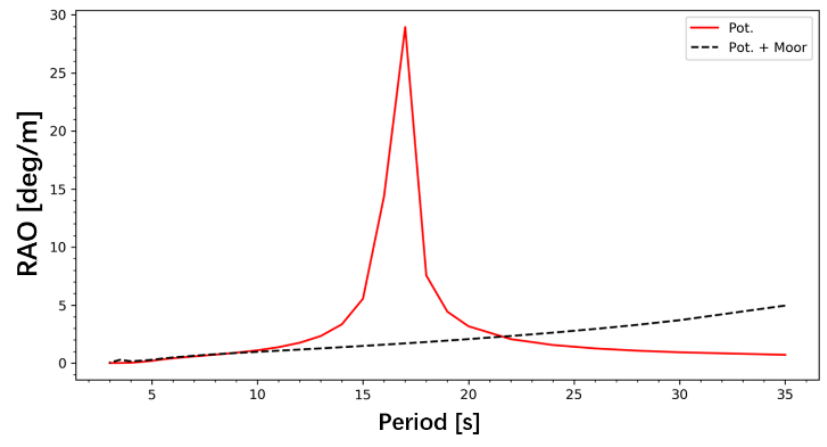

Fig. 14 Pitch RAO with doubled stiffness mooring system compared with potential flow results

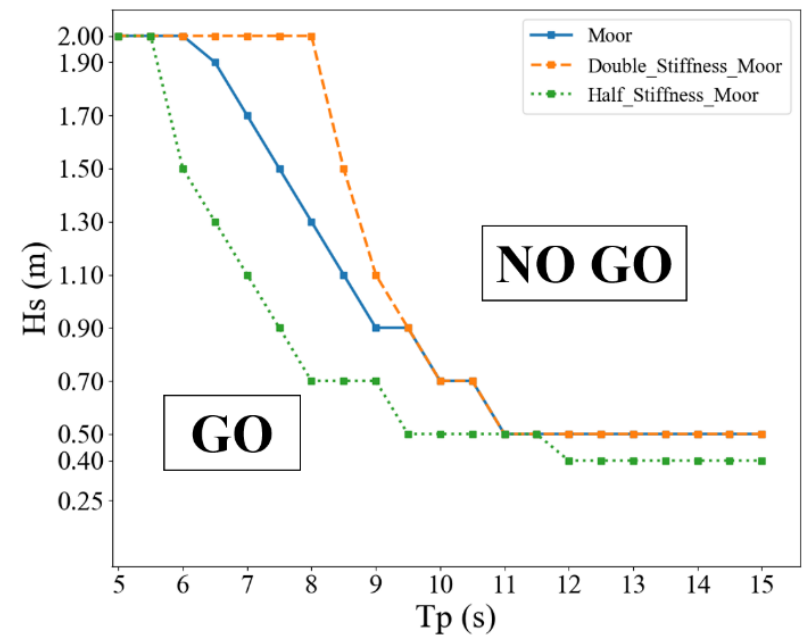

Fig. 15 Comparison of the Go/No Go zones for $32 \mathrm{~m}$ Caisson sizes with different mooring systems in submerged position, criteria $1.0 \mathrm{~m}$ allowable heave motion.

In our calculation of the extra stiffness (restoring) matrix $C_{i j}(\mathrm{i}=1, . .6, \mathrm{j}=1, . .6)$ due to mooring lines, we have assumed that all the mooring lines are in the horizontal plane and on the free surface. Thus, the calculated mooringinduced heave-heave restoring $C_{33}$ is zero, and the heave RAOs are the same no matter if mooring was included. On the other hand, the mooring has a significant impact on the pitch RAOs, thus the final operational limits. The extra pitch stiffness shifted the natural pitch period from around $16 \mathrm{~s}$ (for position 2, 32m caisson, see Fig.5) to around 6s (for 'Pot + Moor', see Fig.13). The possible pitch resonance at lower $T_{p}$ values lead to lower operational limits.

\subsubsection{Drag coefficients}

In previous sections, a rough guess of drag coefficient $C_{d}=$ 25 has been taken for the caisson bottom to avoid unrealistic results. Here in this section, we compare the results based on different drag coefficients, e.g. $C_{d}=20,25$ and 30 to understand how the results may change.

It is seen from Fig.16 and Fig.17 that the drag coefficients have an influence on the heave and pitch RAOs peaks close to the resonant frequencies. Higher drag coefficients contribute to lower response around resonance while affecting only slightly at both ends. The corresponding comparisons of the operation limits are presented in Fig. 18. It is obvious from the comparison that a higher drag coefficient leads to a larger operational window for long waves, while no influences are seen for waves less than $7.5 \mathrm{~s}$. Extra stiffness from the mooring system has not been considered in the results presented in Fig.16 - 18. However, as we have seen from the sensitivity study on mooring stiffness, care should be paid to the mooring system design as it can significantly influence the operational limit, in particular for shorter waves.

Future studies on accurate estimation of the viscous load on the caisson should focus on dedicated experimental or CFD analyses, with special attention on:

* The effects of bilge keel at the bottom of the caisson: It is known from numerous studies (e.g. Cozijn et al. 2005) that the bilge keel can dramatically increase the viscous damping;

* More accurate modeling of drag coefficients considering the caisson and seafloor interaction: The generated vortex from the bilge keel can interact with the seabed, thus influence the viscous loads on the caisson;

- KC-dependent drag coefficients: The relevant $K C$ numbers in our case are not necessarily the same as those in previous studies.

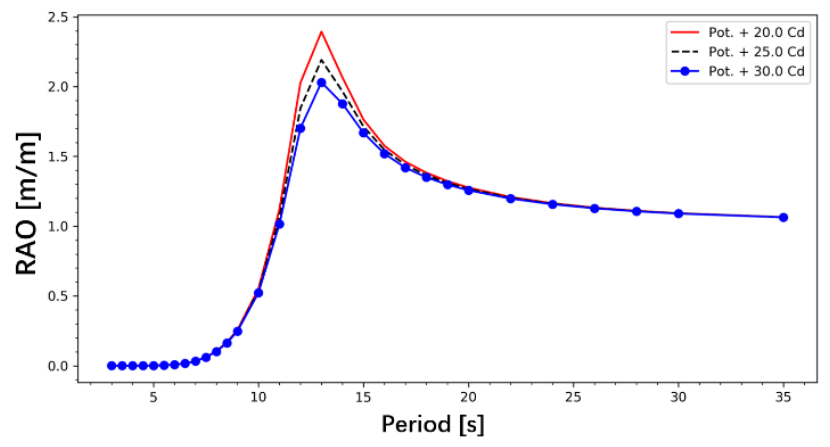

Fig. 16 Heave RAO in submerged position $\mathrm{H}_{\mathrm{mo}}=0.9 \mathrm{~m} \mathrm{Tp}=$ $12.5 \mathrm{~s}$ with three different viscous damping coefficients.

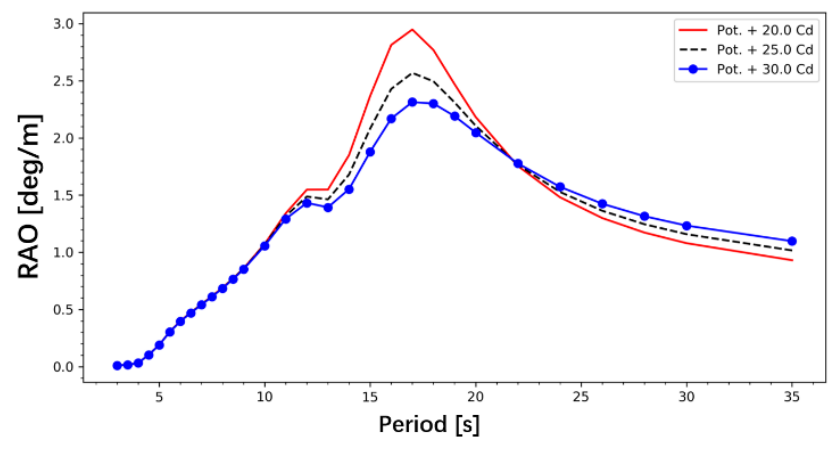

Fig. 17 Pitch RAO in submerged position $H_{m o}=0.9 \mathrm{~m} \mathrm{Tp}=$ $12.5 \mathrm{~s}$ with three different drag coefficients. 

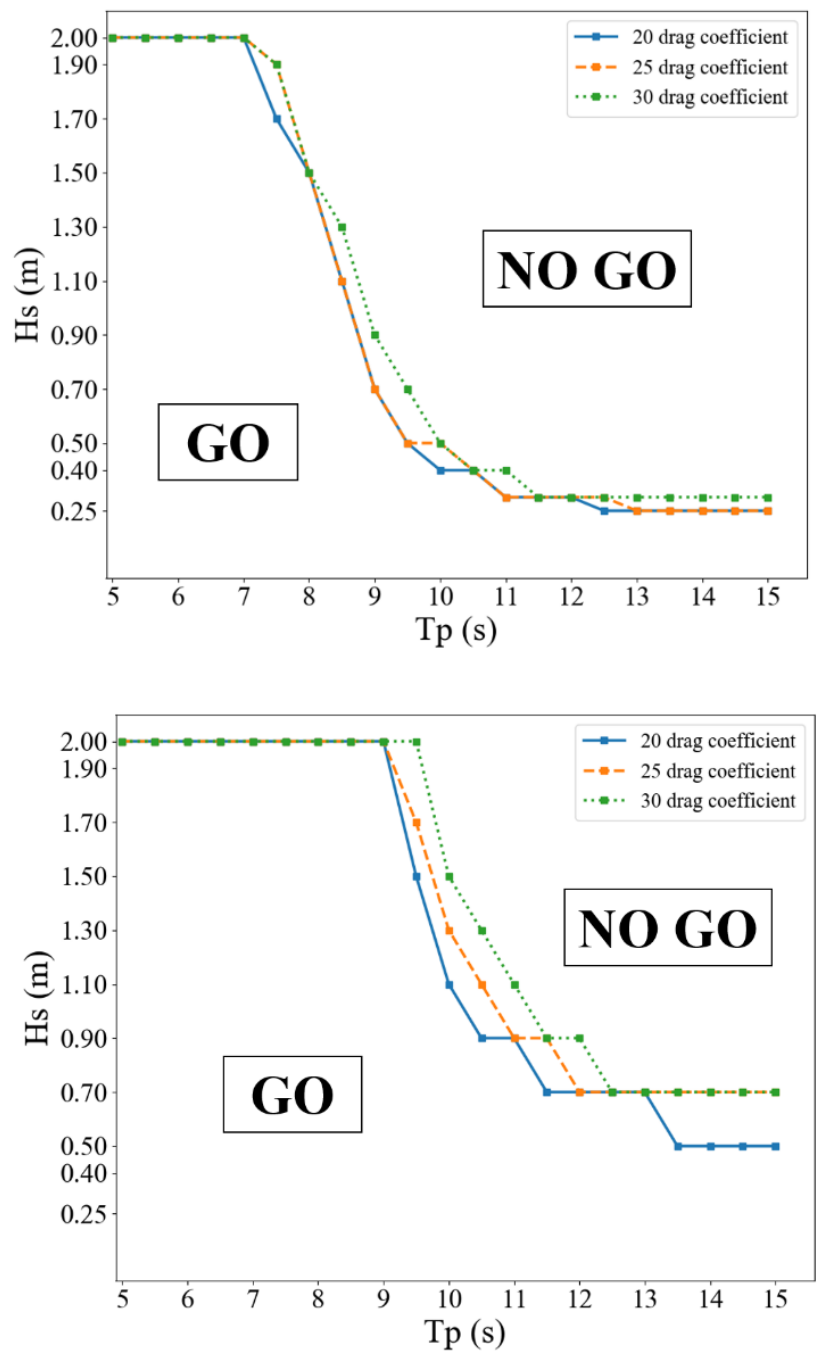

Fig. 18 Comparison of the Go/No Go zones for $32 \mathrm{~m}$ Caisson sizes with different drag coefficients in submerged position, criteria $0.5 \mathrm{~m}$ (upper figure) and $1.0 \mathrm{~m}$ (lower figure) allowable heave motion.

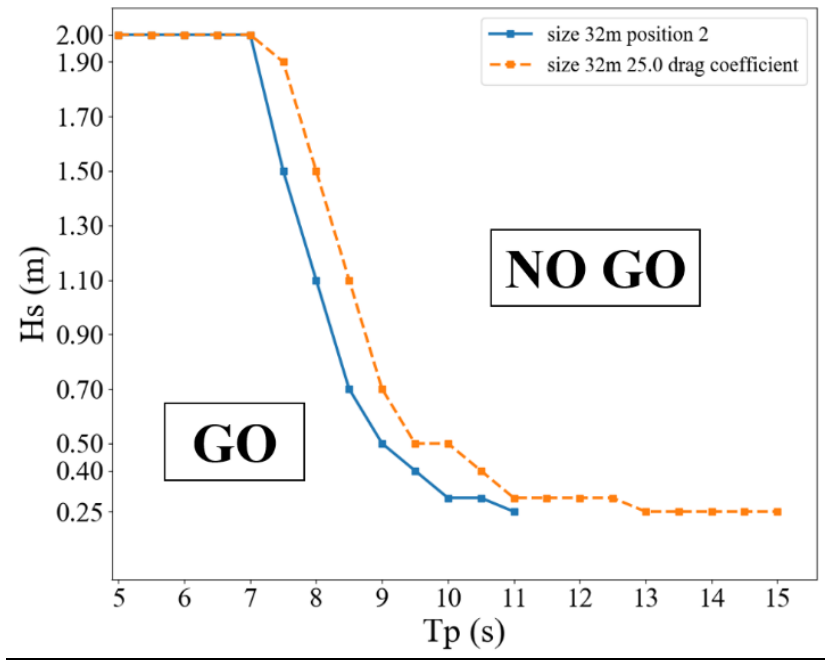

Fig. 19 Caisson size 32 in submerged position with drag $C_{d}=$ 25 , criteria $0.5 \mathrm{~m}$ allowable heave motion.

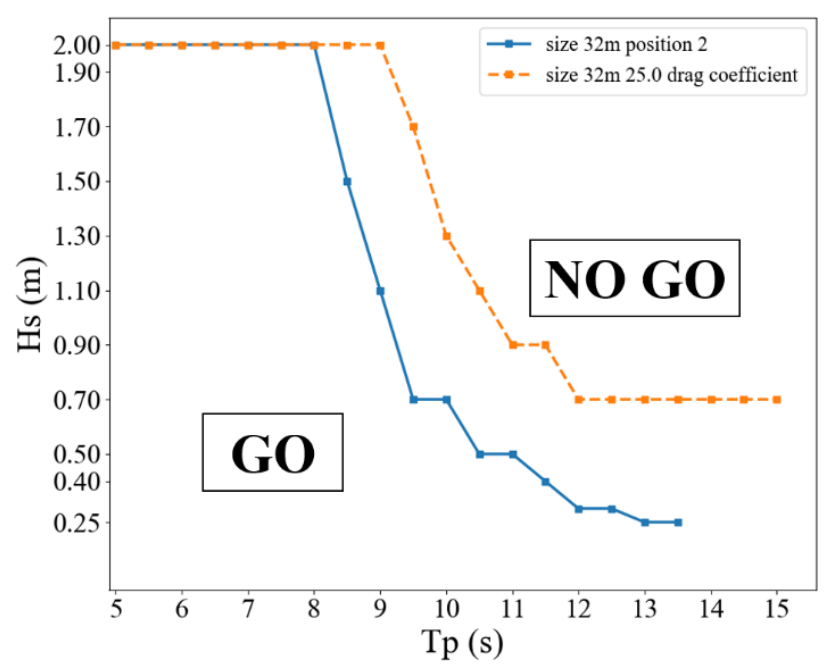

Fig. 20 Caisson size 32 in submerged position with drag $C_{d}=$ 25 , criteria $1.0 \mathrm{~m}$ allowable heave motion.

The mooring system and the damping coefficient contributed by Morison elements are crucial to the operation window. The largest caisson, caisson 1, is considered for further assessment. The comparison of the operation window for the same caisson with $\backslash$ without viscous damping is shown as below in Fig.19 and Fig. 20. The viscous damping shows a slight improvement in the heave motion and therefore on the operational installation window.

\subsubsection{Nonlinearity in added mass due to seafloor effects}

There is another uncertainty in our analysis procedure presented in Section 3. The clearance between the caisson and rubble mound foundation may have strong effects on the added mass and radiation damping coefficients. If this is true, the added mass and radiation-damping coefficient will be dependent on the response amplitudes. For example, when the caisson moves towards the seabed, the added mass will change, thus the inertia of the dynamic system.

Previous results presented in the above sections are based on the calculated added mass using $1 \mathrm{~m}$ clearance below the caisson. As the caisson moves relative to the seabed, the clearance will be changing. Here, three clearances, e.g. $1 \mathrm{~m}, 0.5 \mathrm{~m}$ and $0.2 \mathrm{~m}$, will be used in the hydrodynamic coefficient calculations. The comparison between RAOs in heave and pitch motion of different clearances are displayed in Fig. 21 and Fig. 22. The heave and pitch RAOs for the three clearances are in general quite close, while the responses seem to be slightly larger in case of smaller clearance. 


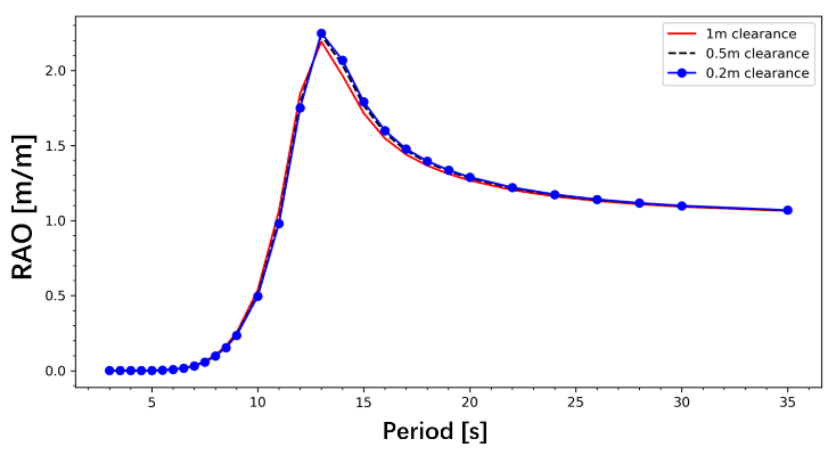

Fig. 21 Heave RAO of caisson size 32 in submerged position $H_{m o}=0.9 m T p=12.5 \mathrm{~s}$ with three different clearances upon sea floor.

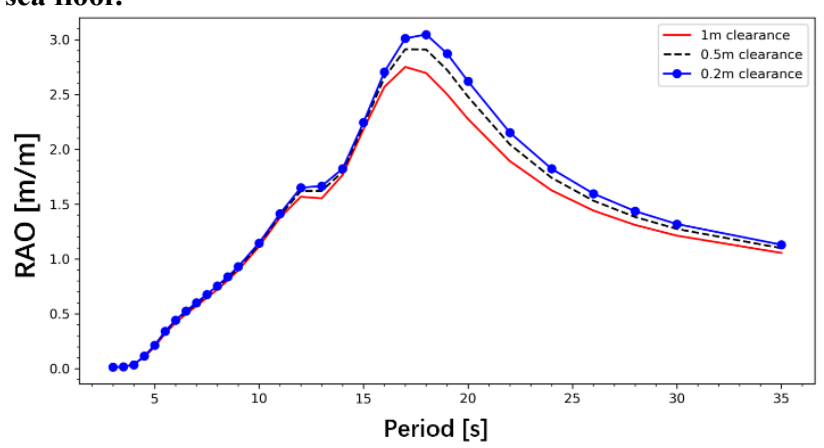

Fig. 22 Pitch RAO of caisson size 32 in submerged position $H_{m o}=0.9 m T p=12.5 \mathrm{~s}$ with three different clearances upon sea floor.

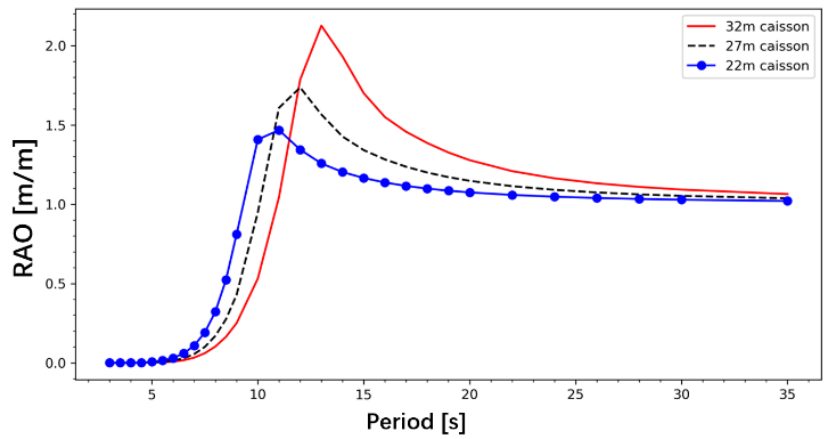

Fig.23 Heave RAO of three sizes caissons in Position 2, $\mathrm{H}_{\mathrm{mo}}$ $=0.9 \mathrm{~m} \mathrm{Tp}=12.5 \mathrm{~s}$ with 25 drag coefficient.

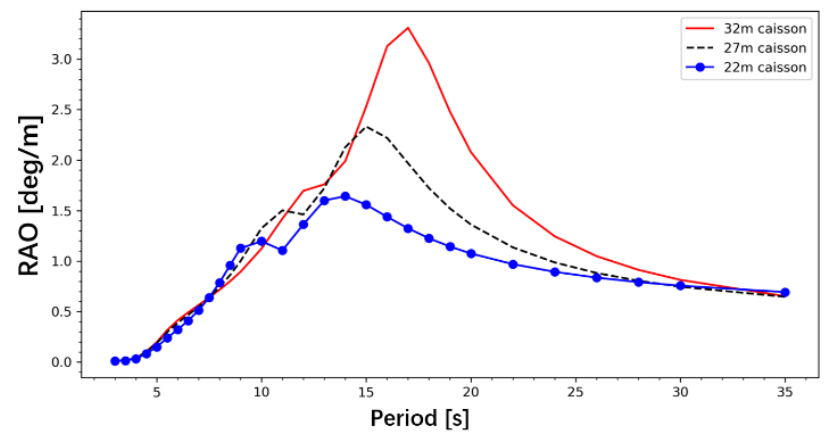

Fig.24 Pitch RAO of three sizes caissons in Position 2, $\mathrm{H}_{\mathrm{mo}}=$ $0.9 \mathrm{~m} T \mathrm{p}=12.5 \mathrm{~s}$ with 25 drag coefficient.

\section{INSTALLATION CONDITIONS}

When a caisson is prepared and ready for the wet-tow to site and installation, the decision to "Go" depended on the weather window for the tow to site and installation. Wave conditions during installation are plotted with the "Go/ No Go" weather window lines. These plots illustrate the acceptable weather window and achieving installation in unfavorable conditions.

The 3-hour most probable maximum values of the vertical motion in each seastate are calculated. For position 1 , no criteria are set as motion can be controlled with more mooring lines or more tension in lines if needed. However, more important here is to compare the results for position 2 in order to have a better understanding of the wave - caisson interaction rather than only defining a limiting criterion on the amplitude of motion.

For position 2, i.e. the immerged position, the caisson is approximately $1 \mathrm{~m}$ above the foundation. The criterion is to make sure the vertical/heave motion of any point on the caisson bottom less than $0.5 \mathrm{~m}$ to avoid collision with a rubble mound foundation. However, the criteria for $1 \mathrm{~m}$ allowable heave motion is assessed as well.

The heave and pitch RAOs for three different caissons with Caisson 1, Caisson 2, Caisson 3: 32m, 27m and 22m height are shown in Fig.23 and Fig. 24 respectively under a sea state of $\mathrm{Hs}=0.9 \mathrm{~m}$ and $\mathrm{Tp}=12.5 \mathrm{~s}$. For the heave RAOs, the largest size, $32 \mathrm{~m}$ height, caisson 1 leads to lower response below wave peak periods of $12 s$ while the smallest size, $22 \mathrm{~m}$ height, caisson 3 gives lower response for high periods. For the pitch RAOs, the obvious differences occur until $15 \mathrm{~s}$ wave peak period and the smallest size, $22 \mathrm{~m}$ height, caisson gives a lower response. The RAOs indicates the tendency of the allowable operation window.

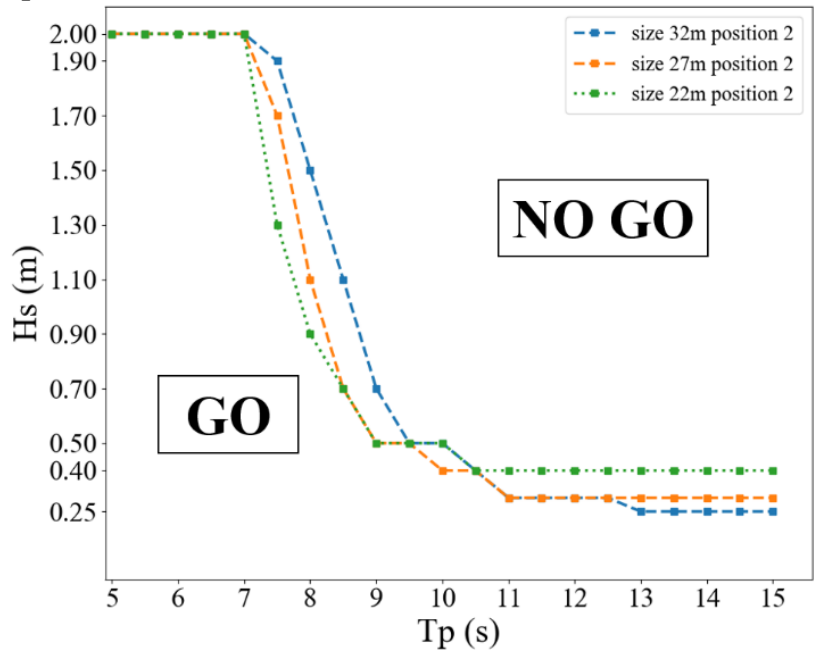

Fig. 25 Comparison of the Go/No Go zones for different Caisson sizes with 25.0 drag coefficient in immersed position (Position 2), criteria $0.5 \mathrm{~m}$ allowable heave motion. 


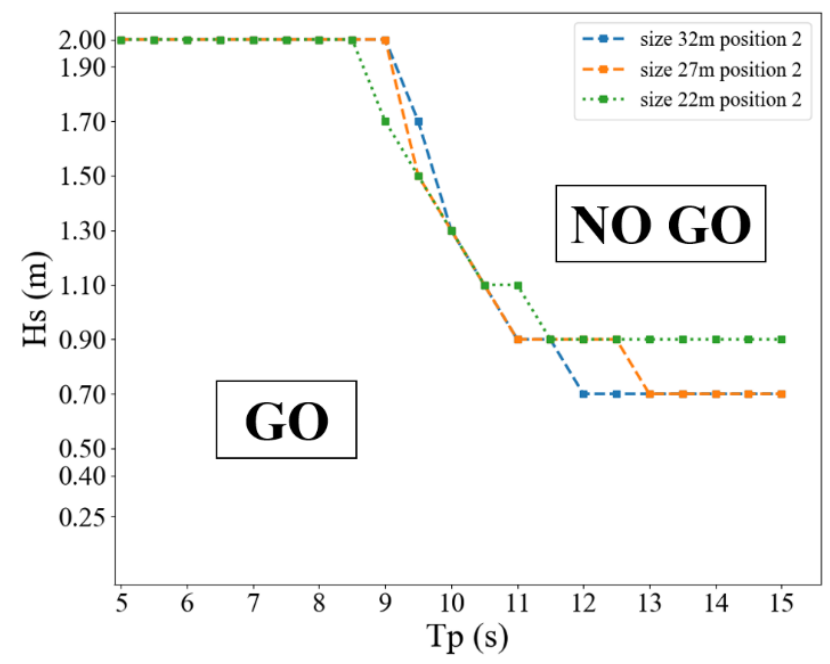

Fig. 26 Comparison of the Go/No Go zones for different Caisson sizes with 25.0 drag coefficient in immersed position (Position 2), criteria $1.0 \mathrm{~m}$ allowable heave motion.

The 'GO / NO GO' plot of installation conditions with viscous damping but without mooring system is presented in Fig.25 and Fig.26, where the left lower zone shows the installation-allowable sea states.

For both $0.5 \mathrm{~m}$ and $1 \mathrm{~m}$ criteria, the comparison between the three curves designating the different caisson sizes shows that the largest caisson (Caisson 1,32m) allows a larger operational weather window when the wave peak period under about $10 \mathrm{~s}$ while the three caissons have almost similar response under longer waves $\mathrm{Tp}=10$ to $15 \mathrm{~s}$ for lightly a higher operational weather window for longer waves. The results show an increase in the operational window for an allowable $1 \mathrm{~m}$ heave motion. It can be therefore concluded that caissons can be installed safely under $\mathrm{Hs}=1.5-2 \mathrm{~m}$ for $\mathrm{Tp}=8-10 \mathrm{~s}$ waves and $\mathrm{Hs}=0.7-0.9 \mathrm{~m}$ for $T p=10-15 \mathrm{~s}$. For $0.5 \mathrm{~m}$ allowable heave motion, more strict wave conditions shall be considered as in Fig. 25.

\section{CONCLUSION AND FUTURE WORK}

Numerical analysis for the wave-caisson interaction is carried out to assess the weather window for safe installation of the caissons. As the caisson size/dimensions vary from project to the other, three caisson sizes have been considered here ranging from approximately 10,000 to 16,000 tons for the concrete weight alone (without any ballast added). The draft varies from 16 to $26 \mathrm{~m}$. The three caissons are of the same width and length but the height varies. Two critical positions of the installation process have been considered. The first, the caisson is floating and waiting for water ballast to sink it in its position and the second where the caisson is immersed and halted at approximately $1 \mathrm{~m}$ above the rubble mound foundation before final placement. A criterion is set up for heave motion not exceeding $0.5 \mathrm{~m}$ and $1 \mathrm{~m}$ in position 2 in order to secure a safe installation and avoid any damage/collision due to excessive caisson motion. The study shows that a larger caisson provides more stability and therefore less motion for wave periods less than 10s. This is mainly due to the weight increase and additional mass as well. For longer waves, $\mathrm{Tp}=10$ to $15 \mathrm{~s}$, the caisson weight is of less importance and the motion is more dominated by restoring forces. The mooring system which showed significant contribution to the pitch and surge motion has little to no impact on the heave motion and therefore will not help to control the caisson movement when close to the mound foundation. The curves established in this study provide guidance on the range of acceptable wave conditions for the installation operations.

It shall be noted that in some projects caissons in the inclined installation method have been used which showed a smaller response/movement for caissons installed horizontally under similar wave conditions. This inclined installation method is not discussed here.

Furthermore, a parametric study is conducted to assess the contribution of the mooring system and viscous damping on the heave, surge and pitch motion of the caisson. A sensitivity analysis is made to assess the impacts of the considered values for drag coefficient, added mass and the stiffness of the mooring system.

Various shapes like cross section of caissons might have diverse results which can be studied in future. Mooring systems mainly affect the response of caisson in low wave period region while different drag coefficients have mostly impact around resonance wave period. The seabed effect is quite limited for this case.

Future study should focus on accurate determination of drag coefficients as function of clearance between caisson and seafloor, as well as the Keulegan-Carpenter numbers. Clearance-dependence of added mass and radiation damping coefficients may also be considered in a timedomain approach.

\section{ACKNOWLEDGMENTS}

The first and third authors would like to acknowledge DNVGL Digital Solutions for providing access to their software package Sesam.

\section{REFERENCES}

[1] Faltinsen, O.M. (1991), Sea loads on ships and offshore structures, Cambridge University Press.

[2] Borgman, L.E. (1967), Random Hydrodynamic Forces on Objects, Annals of Mathematical Statistics, pp.37-51.

[3] Wolfram, J. (1998), On alternative approaches to linearization and Morison's equation for wave forces, Proc. R. Soc. London, Vol. 455, pp. 2957-2974.

[4] Shao, Y., You, J., and Glomnes, E.B. (2016), Stochastic Linearization and its Application in 
Motion Analysis of Cylindrical Floating Structure With Bilge Boxes." Proceedings of the ASME 2016 35th International Conference on Ocean, Offshore and Arctic Engineering. Volume 1: Offshore Technology; Offshore Geotechnics. Busan, South Korea. June 19-24, 2016. V001T01A016. ASME.

[5] Shao, Y., Xiang, X., and Liu, J. (2019), Numerical Investigation of Wave-Frequency Pontoon Responses of a Floating Bridge Based on Model Test Results. Proceedings of the ASME 2019 38th International Conference on Ocean, Offshore and Arctic Engineering. Volume 1: Offshore Technology; Offshore Geotechnics. Glasgow, Scotland, UK. June 9-14, 2019. V001T01A019. ASME.

[6] Innovation in construction Installation of Caisson Breakwater at Costa Azul, Mexico Warren HibbsCostain Ltd., Maidenhead, England, Paul BowersCostain Ltd., Maidenhead, England, Martin YoungScott Wilson Ltd., Basingstoke, England, and James DingwallNoble Denton Ltd., London, England 20101: 316327

[7] Cozijn, J.L., Uittenbogaard, R. and ter Brake, E. (2005), Heave, Roll and Pitch Damping of a Deepwater CALM Buoy with a Skirt, ISOPE2005jsc-409, ISOPE Conference, Seoul, 2005.

[8] Xiang X., et al. (2017), Viscous damping modeling of floating bridge pontoons with heaving skirt and its impact on bridge girder bending moments. The $36^{\text {th }}$ International Conference on Ocean, Offshore and Arctic Engineering, June 25-30, 2017, Trondheim, Norway.

[9] Tao L., and Thiagarajan, K. (2003). Low KC flow regimes of oscillating sharp edges I. Vortex shedding observation. Applied Ocean Research, 25(1), pp. 2135.

[10] Tao L., and Thiagarajan K., (2003), Low KC flow regimes of oscillating sharp edges II. Hydrodynamic forces. Applied Ocean Research 25, pp.53-62. 